\title{
Effect of Thermal and Cycloheximide Treatments on Infection Behaviors of Avirulent Pyricularia oryzae Cavara in Rice Leaf-Sheath*
}

\author{
Sakae ARASE** and Toshiaki OKa**
}

Key Words : Pyricularia oryzae, pathogenicity, aggressiveness, induced susceptibility.

It has been well documented that blast fungus (Pyricularia oryzae Cavara) loses its ability of lesion formation on rice plant during serial subculture on $\mathrm{PSA}^{1}$. It was anticipated that the accumulation of many observations on such pathogenicity-lost (avirulent) isolates may provide valuable informations on the elucidation of aggressiveness and pathogenicity of $P$. oryzae. Therefore, in this study, it was investigated whether or not these avirulent isolates possess the ability of the appressorium formation, insertion of infection hypha and/or the development of hyphae from firstly invaded cells. Further, the effect of thermal and cycloheximide (CY) treatments before inoculation on the behaviors of avirulent blast fungus was investigated. The abstract was partly repored elsewhere ${ }^{2}$.

The rice cultivars, Shin 2, Aichi-asahi and Kanto 51, and fresh onion were used. Each cultivar was raised as described previously ${ }^{3}$. Virulent isolate Hoku 1 (race 007) and avirulent isolates Naga $69-73$ and Ken $62-78$ of P. oryzae was used. All isolates were grown on oat meal medium, and their conidia were obtained as described previously ${ }^{3)}$. Penetration and hyphal growth of P. oryzae in leaf-sheaths treated with heat and CY were determined by Takahashi's method ${ }^{4}$.

As shown in Table 1, over 90\% of conidia of two avirulent isolates (Naga 69-73, Ken 62-78) germinated well and formed appressorium on the sheath tissues of the cv. Shin $224 \mathrm{hr}$ after inoculation. Although there was difference in rate of infection hypha formation between virulent and avirulent isolate, appressoria of avirulent isolates inserted infection hyphae into the sheath cells. The growth of infection hyphae of avirulent isolates was very poor into the rice cells. When these two isolates were inoculated to the nine differential cultivars, no lesion formation was observed on the rice leaves of the all cultivars. Then, in order to elucidate such invading ability of avirulent isolates

* This study was supported in part by Research Grant No. 57360004 from the Ministry of Education, Science and Culture of Japan.

** Faculty of Agriculture, Shimane University, Matsue 690, Japan 島根大学農学部

1) Kozaka, T. (1980). In Blast Disease and Breeding for Resistant Varieties of Rice (Yamasaki, Y. and Kozaka, T. eds.), Hakuyusha, Tokyo. pp. 367-384. 2) Arase, S., Oka, T. and Yamanaka, K. (1985). Ann. Phytopath. Soc. Japan $51: 87$ (Abstr.). 3) Arase, S., Katsuta, M. and Itoi, S. (1983). Ibid. 49 : 689-703. 4) Takahashi, Y. (1951). Hokkaido Pref. Agr. Expt. Sta. Rept. 3: 1-61. 
Table 1. Infection behaviors of Pyricularia isolates on rice leaf-sheath of the cv. Shin 2

\begin{tabular}{l|c|c|c}
\hline \multicolumn{1}{c|}{ Isolate } & $\begin{array}{l}\text { Conidial } \\
\text { germination }\end{array}$ & $\begin{array}{c}\text { Appressorial } \\
\text { formation }\end{array}$ & $\begin{array}{c}\text { Infection hypha } \\
\text { formation }\end{array}$ \\
\hline Hoku 1 (virulent) & $96.8 \%$ & $62.7 \%$ & $41.5 \%$ \\
Ken 62-78 (avirulent) & 95.0 & 73.4 & 4.1 \\
Naga 69-73 (avirulent) & 95.9 & 64.6 & 3.8 \\
\hline
\end{tabular}

Inner surface of leaf-sheath was inoculated with conidial suspension of P. oryzae, and was incubated in a moist chamber at $26 \mathrm{C}$, After $24 \mathrm{hr}$, the rates of conidial germination, appressorial and infection hypha formation were observed.

more clearly, infection behaviors were investigated by onion epidermal strip method ${ }^{5)}$. Conidial suspension of $P$. oryzae was dropped on the well-washed epidermis. As shown in Table 2, two avirulent isolates germinated well and formed appressorium, and appressoria inserted infection hyphae into the onion cells as in case of the sheath tissues of the cv. Shin 2.

Table 2. Infection behaviors of Pyricularia isolates on fresh epidermis of onion

\begin{tabular}{|c|c|c|c|c|c|c|}
\hline \multirow{3}{*}{ Isolate } & \multicolumn{6}{|c|}{ Time after inoculation } \\
\hline & \multicolumn{3}{|c|}{$24 \mathrm{hr}$} & \multicolumn{3}{|c|}{$48 \mathrm{hr}$} \\
\hline & $G^{a)}$ & $A^{b)}$ & $\left.I^{c}\right)$ & G & A & I \\
\hline Hoku 1 (virulent) & 99.0 & 95.6 & 66.2 & $\ldots d)$ & - & - \\
\hline Ken $62-78$ (avirulent) & 97.4 & 90.4 & 23.9 & 99.4 & 99.5 & 36.9 \\
\hline Naga 69-73 (avirulent) & 98.7 & 97.6 & 10.8 & 97.9 & 98.0 & 12.8 \\
\hline
\end{tabular}

The well-washed epidermis of onion was inoculated with conidial suspension of $P$. oryzae, and was incubated in a moist chamber at $26 \mathrm{C}$.

a) Conidial germination (\%). b) Appressorial formation (\%).

c) Infection hypha formation $(\%)$. d) Not observed.

When leaf-sheaths of rice plants (cvs. Shin 2 and Aichi-asahi) were immersed in hot water at $55 \mathrm{C}$ for 10 or $15 \mathrm{sec}$ and were inoculated with conidia of avirulent isolates (Naga 69-73, Ken 62-78), the average value of hyphal growth of avirulent isolates increased, and most invaded hyphae developed from the firstly invaded cells into the neighbouring cells $24 \mathrm{hr}$ after inoculation and infection behaviors resembling those of virulent conidia were observed (Fig. 1). There was no difference between the treatments at $55 \mathrm{C}-10 \mathrm{sec}$ and $55 \mathrm{C}-15 \mathrm{sec}$ in degree of hyphal growth in the sheath cells. While, there was significant difference in rate of penetration to the sheath cells among isolates used. The penetration rate of isolate Ken 62-78 in heat-treated sheath was higher than that of the control, while, in case of isolate Naga 69-73, the rate was lower than that of isolate Ken $62-78$.

When conidia of avirulent isolate Naga 69-73 were inoculated to leaf-sheath of the cv. Kanto 51, which had been preliminarily immersed in CY solution at 5-10 $\mu \mathrm{g} \mathrm{ml}^{-1}$ for

5) Homma, Y., Arimoto, Y., Takahashi, H. and Misato, T. (1983). J. Pesticide Sci. $8:$ 371-377. 


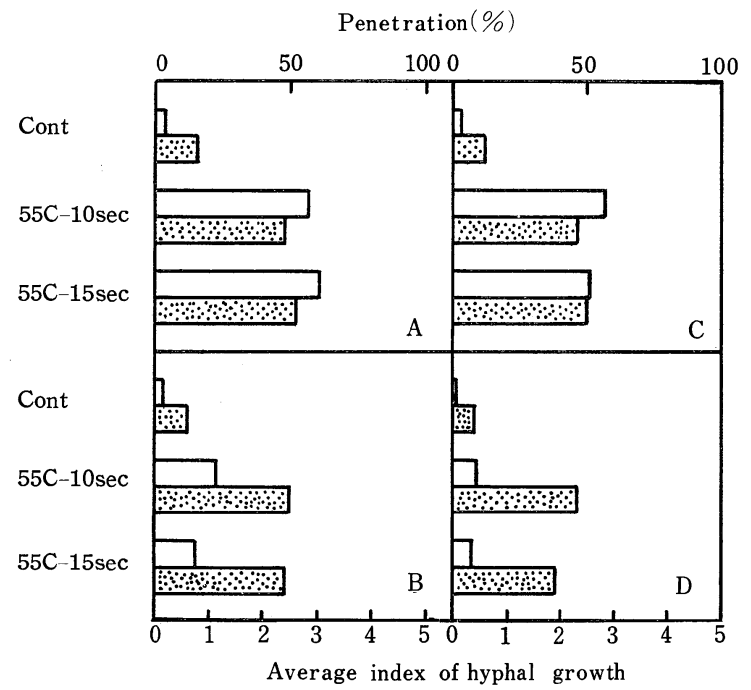

Fig. 1. Effect of thermal treatment on penetration $(\square)$ and hyphal growth (ख) of avirulent $P$. oryzae in leaf-sheath. Detached sheaths of the cvs. Shin 2 and Aichi-asahi were immersed in hot water at $55 \mathrm{C}$ for 10 or $15 \mathrm{sec}$ and were inoculated with isolates Naga 69-73 and Ken 62-78 of P. oryzae. Penetration and hyphal growth were observed at $24 \mathrm{hr}$ after inoculation. A : Ken 62-78 $\times$ cv. Shin 2. B: Naga 69-73 × cv. Shin 2. C:Ken 62-78 × cv. Aichiasahi. D: Naga $69-73 \times$ cv. Aichi-asahi.

$8 \mathrm{hr}$, penetration rate into the sheath cells increased as compared with the control. In addition, infection hyphae of avirulent isolate developed well into the sheath cells and their behavior resembled with that of compatible race-cultivar relation. As shown in Fig. 2, the promotion of the penetration and hyphal growth by CY treatment decreased gradually depending on the increase of the concentration of $\mathrm{CY}$, and no more effect of CY was observed at the concentration of 25 and $50 \mu \mathrm{g} \mathrm{ml}{ }^{-1}$.

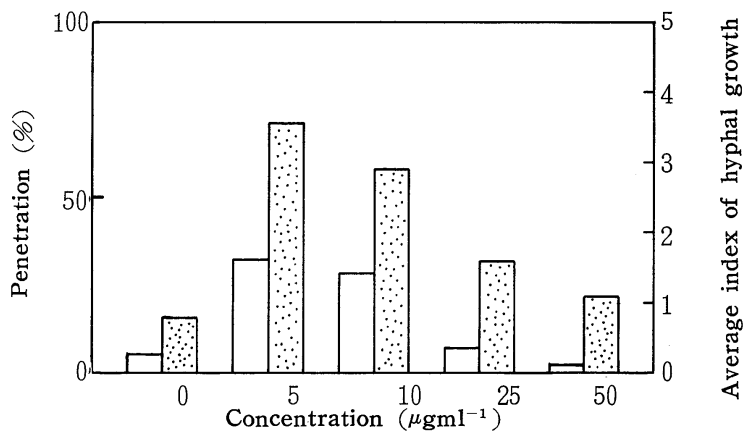

Fig. 2. Effect of cycloheximide on penetration ( $\square$ ) and hyphal growth (ख) of avirulent P. oryzae in leaf-sheath. Part of vasucular bundle tissues (Vbt) of detached leaf-sheaths (cv. Kanto 51) was eliminated by a razor. Then, Vbt-eliminated sheaths of about $5 \mathrm{~cm}$ in length were immersed in cycloheximide solution of several different concentrations $\left(5,10,25,50 \mu \mathrm{gml}^{-1}\right)$. After $8 \mathrm{hr}$, inner surface of Vbt-eliminated sheaths was inoculated with isolate Naga $69-73$ of avirulent $P$. oryzae. Penetration and hyphal growth were observed at $40 \mathrm{hr}$ after inoculation. 
Even avirulent isolates of $P$. oryzae formed appressoria and inserted infection hyphae into the sheath cells, while penetration and hyphal growth were very poor. However, as shown in Figs. 1 and 2, it was observed that penetration and hyphal growth of avirulent isolates increased remarkably into the sheath cells which had been preliminarily treated with hot water and CY. Many hypothesis can be devised to explain this remarkable fungal growth. For example, in the case of thermal treatment, the morphological, physiological or biochemical functions of the host plant concerning the blast resistance may be affected. On the other hand, CY which is generally considered to be an inhibitor of protein synthesis may inhibit de novo protein synthesis concerning blast resistance. Another possibility may be that these two treatments of leaf-sheaths facilitate absorption of nurishment of avirulent $P$. oryzae into the sheath cells. Further investigations are required to elucidate these points.

The authors are grateful to Professor S. Nishimura, Nagoya University, for useful advices and critical reading of the manuscript, and to Dr. M. Yamada, Hokuriku National Agricultural Experiment Station, for supplying avirulent isolates of $P$. oryzae.

\section{和 文 摘 要}

荒瀬 栄・岡 敏明：イネ葉鞘における病原性をなくしたイネいもち病菌の感染行動に及ほすす熱とシクロヘ キシミド処理の影響

イネ品種新 2 号と愛知旭の葉鞘を接種前に $55 \mathrm{C}$ の温湯で10秒ないし15秒処理しておくと, 病原性をなくした イネいもち病菌長69-73之研62-78の侵入率と侵入菌系の伸展度が增加した。さらに, 多くの侵入菌系は接種 24 時間後には第 1 次侵入細胞から隣接細胞に向って伸展していた。また，あらかじめシクロへキシミド溶液で

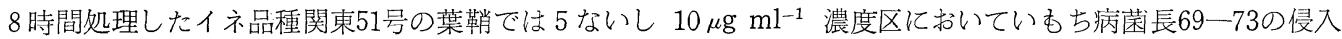
率と侵入菌系の伸展度が増加した。これらの感染行動は親和性レース一品種相互関係のそれに似ていた。

(Received March 27, 1985) 